\title{
Intramolecular cyclizations of $N$-acyliminium ions with pyridine rings
}

\author{
Albert Padwa* and Michael A. Brodney \\ Department of Chemistry, Emory University, Atlanta, GA 30322, USA \\ E-mail: chemap@emory.edu
}

Dedicated to Professor Charles W. Rees on the occasion of his $75^{\text {th }}$ birthday

(received 22 Mar 02; accepted 06 Jul 02; published on the web 14 Jul 02)

\begin{abstract}
The reaction of $N$-Acyliminium ions with several activated pyridines resulted in an intramolecular cyclization to provide novel heterocycles. The reaction exhibited a regiochemical preference for cyclization para to the electron donating substitutent.
\end{abstract}

Keywords: N-Acyliminium ions, intramolecular cyclizations, pyridines, regiochemical

\section{Introduction}

The use of electron rich aromatic rings for cationic $\pi$-cyclizations ${ }^{1}$ has emerged as a powerful method for the construction of novel heterocycles and natural products. ${ }^{2}$ These cyclizations have been utilized as the key carbon-carbon bond forming reaction in the synthesis of several alkaloids, including the tetrahydroisoquinoline, $\beta$-carboline, and lycopodium classes. From a synthetic standpoint, iminium and $N$-acyliminium ions have emerged as powerful electrophiles for these reactions, allowing for an overall $\alpha$-imido alkylation. ${ }^{4,5}$ The $\pi$-systems typically employed in these cyclizations are electron rich aromatics ${ }^{6}$ as well as allyl ${ }^{7}$ and vinyl silanes. In contrast, the pyridine ring has received very little attention as a potential nucleophilic partner in cationic $\pi$-cyclizations despite its prevalence in a wide variety of biologically important heterocycles. ${ }^{9}$ This is not so surprising as the electron-withdrawing effect of nitrogen in pyridine makes this heterocycle considerably less reactive than benzene toward electrophiles.

Electrophilic attack at carbon is further complicated in that these reactions are often carried out in highly acidic conditions, which means that the reacting species is often the more electrondeficient conjugate acid. When electrophilic attack does occur, it is generally at the ring nitrogen. An obvious corollary of this ease of reaction of electrophilies with the ring nitrogen 
atom is that electrophilic heteroaromatic substitution of the $\pi$-deficient heterocycle is exceptionally difficult. Thus, nitration, sulfonation, and halogenation of pyridine requires drastic conditions and yields of the expected 3 -substituted products are very low. ${ }^{11}$ In this paper, the intramolecular cationic $\pi$-cyclization of pyridines of type $\mathbf{1}$ with tethered $N$-acyliminium ions is described.

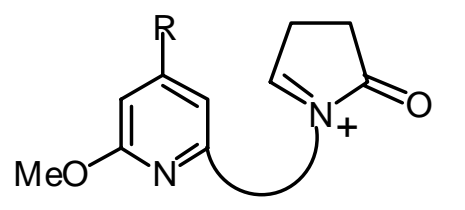

1

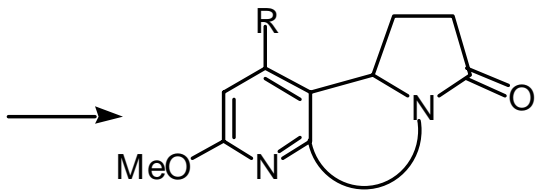

2

\section{Results and Discussion}

Preparation of lactam 7 was accomplished in four steps in good overall yield starting from the appropriate hydroxy pyridine derivative (Scheme 1). Commercially available 2-hydroxy-6methyl pyridine (3) was protected with $\mathrm{MeI}$ in the presence of $\mathrm{Ag}_{2} \mathrm{CO}_{3}$ to furnish 2-methoxy-6methyl pyridine (4) in quantitative yield. ${ }^{12}$
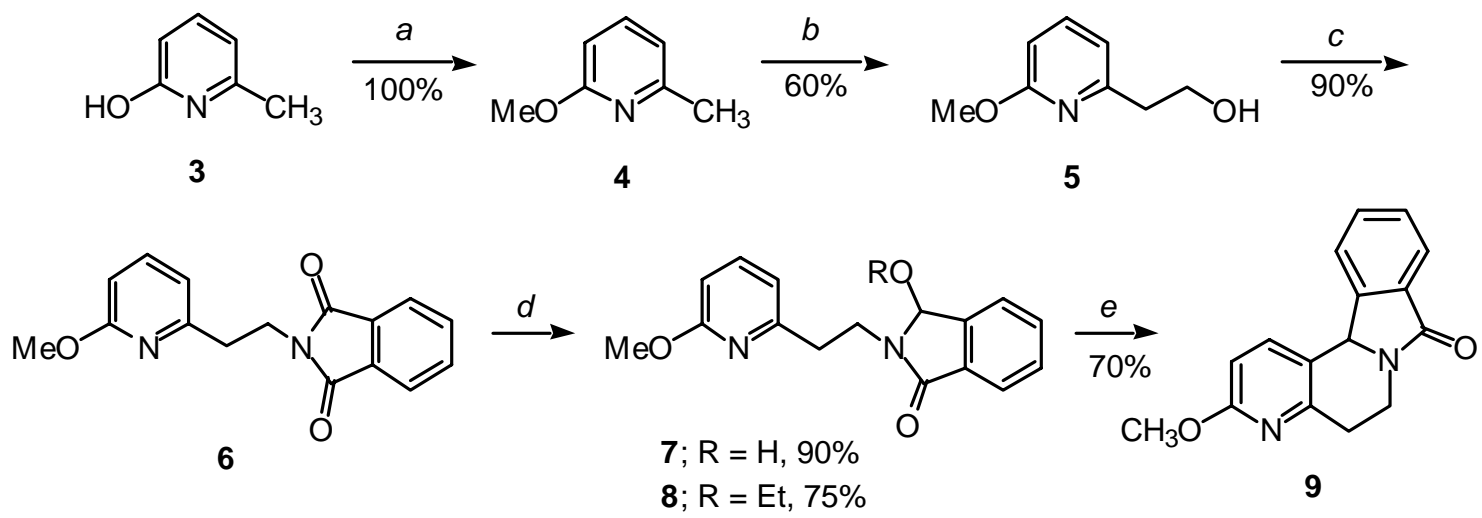

Conditions : (a) $\mathrm{Ag}_{2} \mathrm{CO}_{3}, \mathrm{Mel}, \mathrm{CH}_{2} \mathrm{Cl}_{2}$; (b) $n$-BuLi, THF, $0{ }^{\circ} \mathrm{C},\left(\mathrm{CH}_{2} \mathrm{O}\right)_{n}$, rt; (c) $\mathrm{PPh}_{3}$, DEAD, phthalimide, THF, rt; (d) $\mathrm{Li}(\mathrm{Et})_{3} \mathrm{BH}, \mathrm{THF},-78{ }^{\circ} \mathrm{C}, \mathrm{HCl} / \mathrm{H}_{2} \mathrm{O}$ (or $\mathrm{HCl} / \mathrm{EtOH}$ ); (e) $p-\mathrm{TsOH}, \mathrm{C}_{6} \mathrm{H}_{6}, \Delta$

\section{Scheme 1}

Deprotonation of 4 with $n$-BuLi at $-78{ }^{\circ} \mathrm{C}$ followed by quenching with paraformaldehyde afforded the primary alcohol 5 in $60 \%$ yield. Incorporation of the phthalimide functionality was accomplished by nucleophilic substitution using Mitsunobu conditions to provide 6 in $90 \%$ yield. ${ }^{13}$ Reduction of $\mathbf{6}$ to lactams 7 and $\mathbf{8}$ was carried out using super hydride $\left(\mathrm{Li}(\mathrm{Et})_{3} \mathrm{BH}\right)$ at $78^{\circ} \mathrm{C} .{ }^{14}$ Our initial attempts to cyclize lactam 7 or 8 using a variety of Lewis acid conditions 
$\left(\mathrm{BF}_{3} . \mathrm{OEt}_{2}, \mathrm{TiCl}_{4}, \mathrm{ZnCl}_{2}, \mathrm{SnCl}_{4}, \mathrm{BF}_{3} .2 \mathrm{AcOH}\right.$, etc: $)$ were unsuccessful resulting only in recovered starting material or decomposition products. Cationic $\pi$-cyclization was ultimately successful when protic acids such as $p$-TsOH or CSA were used. For example, when lactam 7 was heated in benzene in the presence of a catalytic amount of $p$-toluenesulfonic acid, the desired tetracyclic lactam 9 was obtained in $70 \%$ yield. The same product was isolated in 55\% yield when $\alpha$-ethoxy amide 8 was treated under the above conditions.

In order to probe the regiochemical preference of the reaction, lactam 14 was synthesized in a manner similar to that described above (Scheme 2). 2-Hydroxy-4-methyl-pyridine (10) was converted to the methoxy derivative and then transformed into the phthalimide derivative $\mathbf{1 3}$ in $40 \%$ overall yield. Reduction with super hydride provided lactam 14 in $90 \%$ yield. Treatment of 14 with a catalytic amount of $p$ - $\mathrm{TsOH}$ in benzene at reflux afforded a 3.5:1 mixture of regioisomers in $68 \%$ isolated yield in addition to a dark polymer. Silica gel chromatography of the mixture furnished tetracyclic lactam 15 as the major product arising from electrophilic aromatic substitution para to the electron donating methoxy substituent.

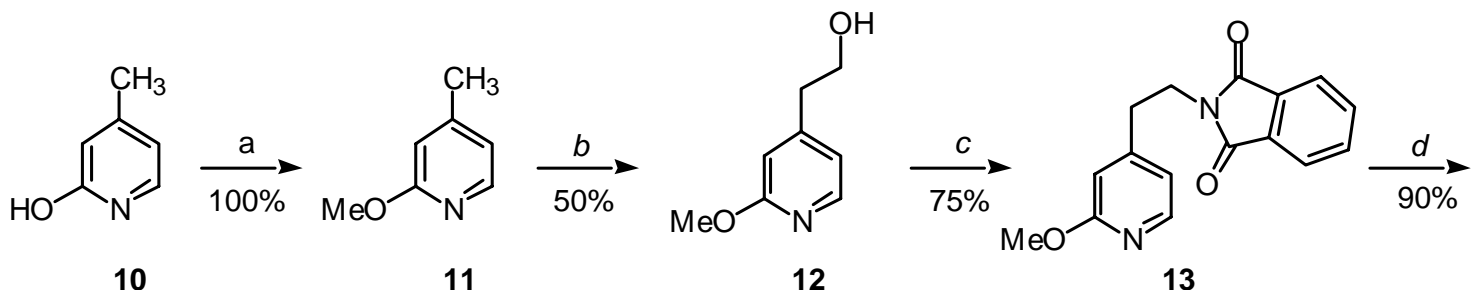

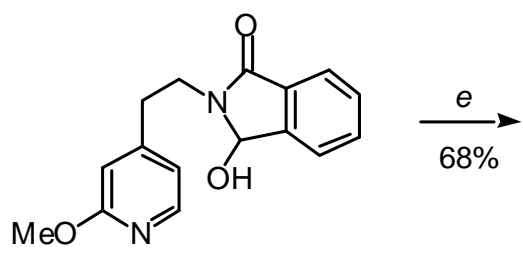

14

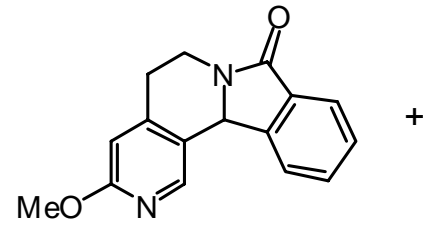

15<smiles>COc1nccc2c1C1c3ccccc3C(=O)N1CC2</smiles>

16

Conditions : (a) $\mathrm{Ag}_{2} \mathrm{CO}_{3}$, Mel, $\mathrm{CH}_{2} \mathrm{Cl}_{2}$; (b) $n$-BuLi, THF, $0{ }^{\circ} \mathrm{C},\left(\mathrm{CH}_{2} \mathrm{O}\right)_{n}$, rt; (c) $\mathrm{PPh}_{3}$, DEAD, phthalimide, THF, rt; (d) $\mathrm{Li}(\mathrm{Et})_{3} \mathrm{BH}, \mathrm{THF},-78^{\circ} \mathrm{C}, \mathrm{HCl} / \mathrm{H}_{2} \mathrm{O}$; (e) $p-\mathrm{TsOH}, \mathrm{C}_{6} \mathrm{H}_{6}, \Delta$

\section{Scheme 2}

The minor product $\mathbf{1 6}$ arises from attack of the $N$-acyliminium ion ortho to the methoxy substituent on the pyridine ring.

Still another example involves the cyclization of lactam 18. 2-(6-Methoxy-pyridin-2yl)ethanol (5) was converted under Mitsunobu conditions to the succinimide derivative in $70 \%$ yield (Scheme 3). Reduction of $\mathbf{1 7}$ to $\mathbf{1 8}$ followed by acid catalyzed cyclization led to the tricyclic lactam 19 in only $30 \%$ yield. All attempts to improve the yield of the cyclization were unsuccessful. The low yield of $\mathbf{1 9}$ is presumably related to proton loss from the $\mathrm{N}$-acyliminium 
ion followed by some alternate pathway. Clearly, the best results are obtained when a $\alpha$ hydrogen is not present on the $N$-acyliminium ion precursor.<smiles>COc1cccc(CCN2C(=O)CCC2O)n1</smiles>

Conditions: (a) $\mathrm{Li}(\mathrm{Et})_{3} \mathrm{BH}, \mathrm{THF},-78{ }^{\circ} \mathrm{C}, \mathrm{HCl} / \mathrm{H}_{2} \mathrm{O}$; (b) $p-\mathrm{TsOH}, \mathrm{C}_{6} \mathrm{H}_{6}, \Delta$

\section{Scheme 3}

The next phase of our investigation involved an attempted cyclization of an electron rich pyridine ring with a $\mathrm{N}$-acyliminium ion generated from an isomünchnone cycloadduct. Earlier studies in our laboratory showed that 1,3-oxazolium-4-oxides (isomünchnones) 21 can be generated by the rhodium(II)-catalyzed cyclization of a suitable diazo imide 20 (Scheme 4). ${ }^{15}$ This type of mesoionic ylide corresponds to the cyclic equivalent of a carbonyl ylide and was found to readily undergo [4+2]-cyclo-addition with suitable dipolarophiles. ${ }^{16}$

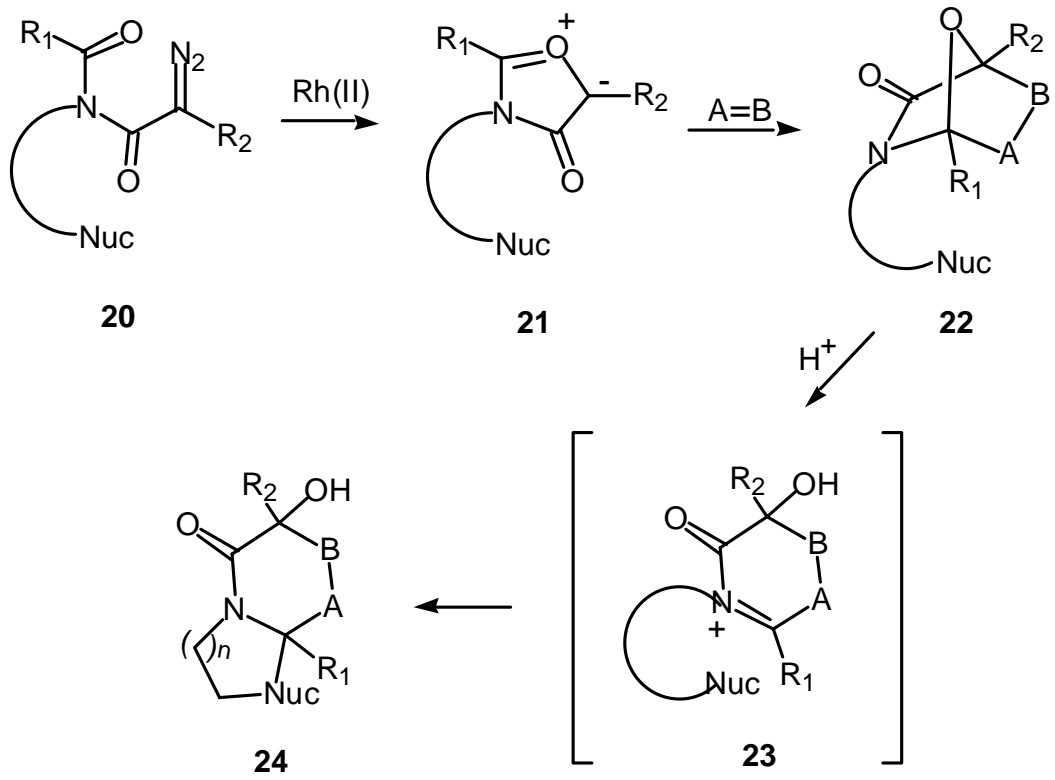

\section{Scheme 4}

Formation of the isomünchnone cycloadduct proceeds by initial generation of a rhodium carbenoid species, followed by an intramole-cular cyclization onto the neighboring carbonyl oxygen to form the mesoionic ylide $21{ }^{16}$ The resultant isomünchnone may be trapped with electron rich or electron deficient dipolarophiles to give cycloadducts 22 in good yield. ${ }^{17}$ These 
uniquely functionalized cycloadducts contain a "masked" $\mathrm{N}$-acyliminium ion which is generated by its treatment with a Lewis or protic acid. ${ }^{18}$ By incorporating an internal nucleophile on the tether, annulation of the original cycloadduct 22 allows for the construction of a more complex nitrogen heterocyclic system ${ }^{19}$

In order to test the above concept it was necessary to prepare a suitable isomünchnone cycloadduct (i.e. 34 or 35) by first constructing the obligatory diazo imide. The synthesis began with commercially available hept-6-enoic acid (26) or citronellic (27) acid (Scheme 5). Treatment of these acids with 1,1-carbonyldiimidazole followed by reaction with 2-(6-methoxypyridin-2-yl)ethyl amine (25) afforded the corresponding amides 28 and 29 in good yield. Amine 25 was prepared by treating imide 13 with hydrazine hydrate in refluxing ethanol. The above amides were subjected to $N$-malonylacylation and the resulting imido esters $\mathbf{3 0}$ and $\mathbf{3 1}$ were then treated with mesyl azide in the presence of triethylamine to provide diazo imides 32 and 33 . $^{20}$

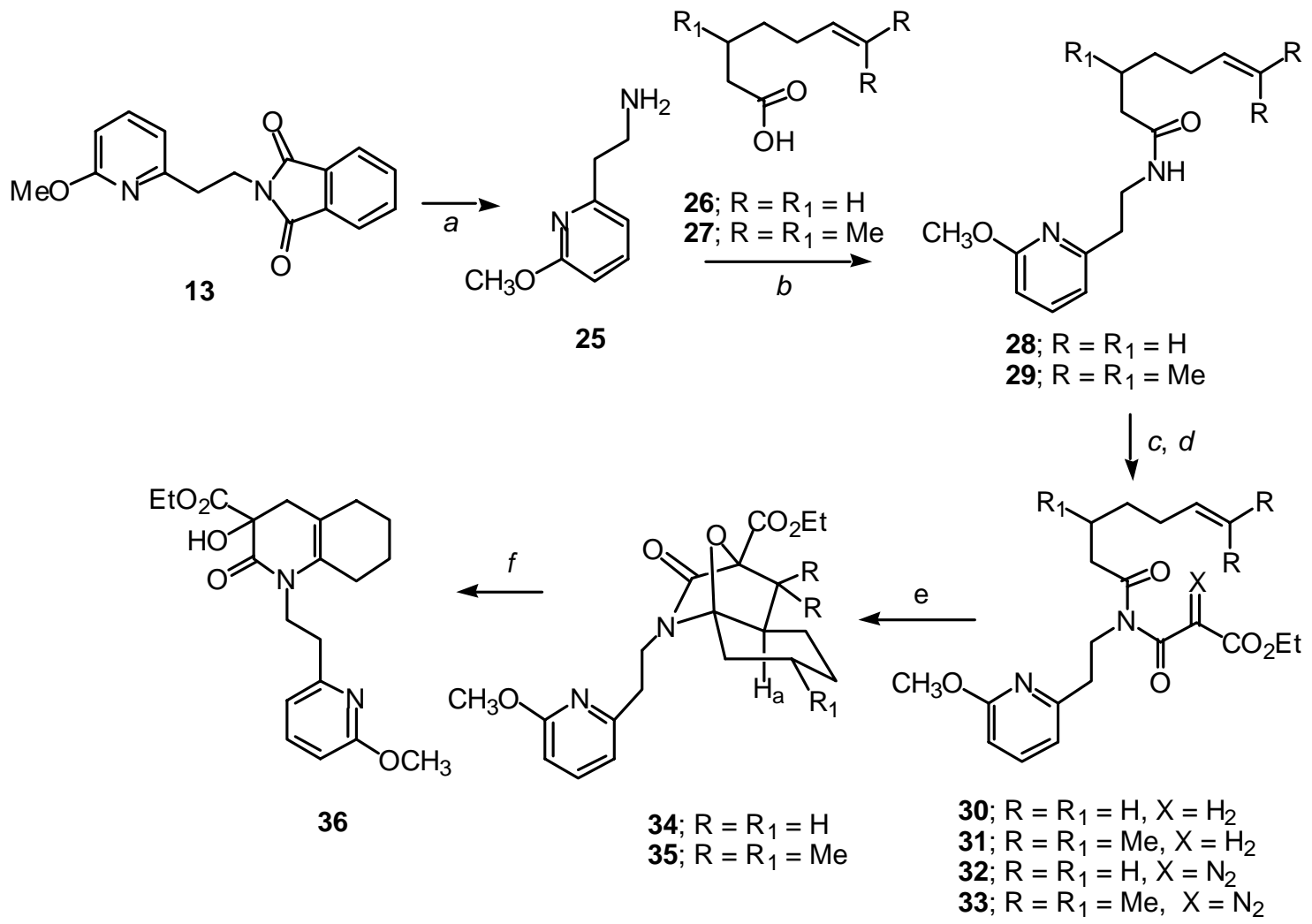

Reagents: (a) $\mathrm{NH}_{2} \mathrm{NH}_{2}$, EtOH, $65^{\circ} \mathrm{C}$; (b) $\mathrm{Im}_{2} \mathrm{CO}, \mathrm{CH}_{2} \mathrm{Cl}_{2}$; (c) $\mathrm{ClCOCH}_{2} \mathrm{CO}_{2} \mathrm{Et}$;

(d) $\mathrm{MsN}_{3}, \mathrm{NEt}_{3} ;$ (e) $\mathrm{Rh}_{2}(\mathrm{pfb})_{4}, \mathrm{CH}_{2} \mathrm{Cl}_{2}, 65^{\circ} \mathrm{C}$; (f) $p$-TsOH, $\mathrm{C}_{6} \mathrm{H}_{6}, \Delta$.

\section{Scheme 5}

Formation of the isomünchnone dipole proceeded smoothly when these diazo imides were 
treated with rhodium(II) perfluorobutyrate in $\mathrm{CH}_{2} \mathrm{Cl}_{2}$ at $25{ }^{\circ} \mathrm{C}$. After the initial generation of the rhodium carbenoid, intramolecular cyclization onto the substituted hex-7-enoic acyl carbonyl oxygen occurred to produce the mesoionic oxazolium ylide which underwent 1,3-dipolar cycloaddition across the pendant olefinic $\pi$-bond. In both cases, the reaction provided the expected cycloadducts $34(92 \%)$ and $35(82 \%)$ as single diastereomers resulting from endo cycloaddition with respect to the dipole. Assignment of the stereochemistry of the cycloadducts was based on a comparison of NMR signals with related substrates synthesized in this laboratory whose structures had been confirmed by X-ray crystallography. ${ }^{18}$ In all cases, the antistereochemistry between the oxa-bridge and the angular proton $\left(\mathrm{H}_{\mathrm{a}}\right)$ was obtained. Unfortunately, all of our attempts to trap the $\mathrm{N}$-acyliminium ion derived from both cycloadducts 34 and 35 using the electron rich pyridine in a Pictet-Spengler type cyclization were unsuccessful. In the case of cycloadduct 34, the 2-oxohexahydroquinolone $\mathbf{3 6}$ was isolated as the sole product in $92 \%$ yield.

In summary, we have shown that, in certain cases, the pyridine nucleus can be utilized as a suitable nucleophilic partner in cationic $\pi$-cyclizations. Although unactivated pyridine rings do not cyclize well, pyridines containing an electron donating substituent cyclize in good yield. The results presented herein demonstrate the potential of using such cyclizations for the synthesis of novel heterocycles and pyridine and pyridone containing natural products.

\section{Experimental Section}

General Procedures. Melting points are uncorrected. Mass spectra were determined at an ionizing voltage of $70 \mathrm{eV}$. Unless otherwise noted, all reactions were performed in flame dried glassware under an atmosphere of dry argon. Solutions were evaporated under reduced pressure with a rotary evaporator and the residue was chromatographed on a silica gel column using an ethyl acetate/hexane mixture as the eluent unless specified otherwise. All solids were recrystallized from ethyl acetate/hexane for analytical data.

2-(6-Methoxy-pyridin-2-yl)ethanol (5). A solution containing $1.0 \mathrm{~g}(8.1 \mathrm{mmol})$ of 2-methoxy5-methyl-pyridine ${ }^{12}$ in $45 \mathrm{~mL}$ of dry THF at $-78{ }^{\circ} \mathrm{C}$ was treated dropwise with $3.6 \mathrm{~mL}$ ( $9.0 \mathrm{mmol})$ of $2.5 \mathrm{M}$ solution of $n-\mathrm{BuLi}$ in hexane. The mixture was stirred at $-78{ }^{\circ} \mathrm{C}$ for $15 \mathrm{~min}$ and then $1.0 \mathrm{~g}(33 \mathrm{mmol})$ of paraformaldehyde was added and the resultant mixture was allowed to gradually warm to $\mathrm{rt}$ and stirred for an additional $5 \mathrm{~h}$. The mixture was quenched with $10 \mathrm{~mL}$ of water and the aqueous phase was extracted with ether. The combined organic layers were washed with $10 \mathrm{~mL}$ of brine and the combined organic layers were dried over sodium sulfate. The solvent was removed under reduced pressure and the residue was purified by flash silica gel chromatography to give $0.5 \mathrm{~g}(50 \%)$ of 5 as a colorless oil: IR (neat) $1599,1578,1465$, and $1041 \mathrm{~cm}^{-1}$; ${ }^{1} \mathrm{H}-\mathrm{NMR}\left(\mathrm{CDCl}_{3}, 300 \mathrm{MHz}\right) \delta 2.92(\mathrm{t}, 2 \mathrm{H}, J=5.4 \mathrm{~Hz}), 3.89(\mathrm{~s}, 3 \mathrm{H}), 3.97$ (t, 2H, $J=$ $5.4 \mathrm{~Hz}), 4.15$ (brs, $1 \mathrm{H}), 6.61(\mathrm{~d}, 1 \mathrm{H}, J=8.1 \mathrm{~Hz}), 6.71(\mathrm{~d}, 1 \mathrm{H}, J=7.2 \mathrm{~Hz})$, and 7.49 (dd, $1 \mathrm{H}, J=$ 
8.1 and $7.5 \mathrm{~Hz}) ;{ }^{13} \mathrm{C}-\mathrm{NMR}\left(\mathrm{CDCl}_{3}, 75 \mathrm{MHz}\right) \delta 38.5,53.5,62.2,108.7,115.9,139.4,158.4$, and 163.7; HRMS Calcd for $\mathrm{C}_{8} \mathrm{H}_{11} \mathrm{NO}_{2}: 153.0790$. Found: 153.0789 .

2-[2-(6-Methoxy-pyridin-2-yl)ethyl]isoindole-1,3-dione (6). A solution of $1.0 \mathrm{~g}(6.0 \mathrm{mmol})$ of diethyl azodicarboxylate in $5 \mathrm{~mL}$ of THF was added to a solution of $0.9 \mathrm{~g}(6.0 \mathrm{mmol})$ of alcohol $5,0.9 \mathrm{~g}(6.0 \mathrm{mmol})$ of phthalimide, and $1.5 \mathrm{~g}(6.0 \mathrm{mmol})$ of triphenylphosphine in $50 \mathrm{~mL}$ THF at $0{ }^{\circ} \mathrm{C}$. The mixture was allowed to warm to $\mathrm{rt}$, stirred for $10 \mathrm{~h}$ and then concentrated under reduced pressure. The crude residue was subjected to flash silica gel chromatography to give $1.5 \mathrm{~g}(90 \%)$ of 6 as a white solid: mp $96-97{ }^{\circ} \mathrm{C}$; IR (neat) $1769,1705,1581,1393$, and $1034 \mathrm{~cm}^{-1} ;{ }^{1} \mathrm{H}-$ NMR $\left(\mathrm{CDCl}_{3}, 300 \mathrm{MHz}\right) \delta 3.06$ (t, $\left.2 \mathrm{H}, J=7.2 \mathrm{~Hz}\right), 3.76(\mathrm{~s}, 3 \mathrm{H}), 4.09$ (t, $\left.2 \mathrm{H}, J=7.2 \mathrm{~Hz}\right), 6.53$ (d, 1H, $J=$ $8.1 \mathrm{~Hz}), 6.70(\mathrm{~d}, 1 \mathrm{H}, J=7.2 \mathrm{~Hz}), 7.42(\mathrm{dd}, 1 \mathrm{H}, J=7.5$ and $7.5 \mathrm{~Hz}), 7.67-7.70(\mathrm{~m}, 2 \mathrm{H})$, and 7.79-7.82 $(\mathrm{m}, 2 \mathrm{H}) ;{ }^{13} \mathrm{C}-\mathrm{NMR}\left(\mathrm{CDCl}_{3}, 75 \mathrm{MHz}\right) \delta 36.1,37.8,53.2,108.7,115.9,123.3,132.4,134.0$, 139.0, 156.1, 163.8, and 168.4; Anal. Calcd for $\mathrm{C}_{16} \mathrm{H}_{14} \mathrm{~N}_{2} \mathrm{O}_{3}$ : C, 68.08; N, 9.92; H, 5.00. Found: C, 68.18; N, 9.88; H, 5.05.

3-Hydroxy-2-[2-(6-methoxy-pyridin-2-yl)ethyl]-2,3-dihydro-isoindol-1-one (7). To a solution of $0.2 \mathrm{~g}(0.7 \mathrm{mmol})$ of phthalimide 6 in $10 \mathrm{~mL}$ of THF at $-78^{\circ} \mathrm{C}$ was added $2.8 \mathrm{~mL}(3.0 \mathrm{mmol})$ of a $1.0 \mathrm{M}$ lithium triethylborohydride solution. The reaction mixture was allowed to stir for $15 \mathrm{~min}$ and then quenched with $1 \mathrm{~mL}$ of $10 \% \mathrm{HCl}$, diluted with sodium carbonate, and extracted with ether. The combined organic layers were dried over magnesium sulfate and concentrated under reduced pressure. The crude residue was subjected to flash silica gel chromatography to give $0.18 \mathrm{~g}(90 \%)$ of 7 as a white solid: $\mathrm{mp} 98-99{ }^{\circ} \mathrm{C}$; IR (neat) $1682,1600,1578$, and $1280 \mathrm{~cm}^{-}$ '; ${ }^{1} \mathrm{H}-\mathrm{NMR}\left(\mathrm{CDCl}_{3}, 300 \mathrm{MHz}\right) \delta$ 2.94-3.03 (m, $\left.1 \mathrm{H}\right), 3.10-3.20(\mathrm{~m}, 1 \mathrm{H}), 3.61(\mathrm{~s}, 3 \mathrm{H}), 3.72-3.81$ $(\mathrm{m}, 1 \mathrm{H}), 3.93-4.02(\mathrm{~m}, 1 \mathrm{H}), 5.62(\mathrm{~s}, 1 \mathrm{H}), 5.75(\mathrm{~s}, 1 \mathrm{H}), 6.51(\mathrm{~d}, 1 \mathrm{H}, J=8.4 \mathrm{~Hz}), 6.75(\mathrm{~d}, 1 \mathrm{H}, J=$ 7.2 Hz), and 7.36-7.57 (m, 5H); ${ }^{13} \mathrm{C}-\mathrm{NMR}\left(\mathrm{CDCl}_{3}, 75 \mathrm{MHz}\right) \delta 36.1,39.4,53.5,82.8,108.5$, 116.5, 123.2, 123.3, 129.6, 131.6, 132.2, 139.6, 144.5, 156.8, 163.7, and 167.5; Anal. Calcd for $\mathrm{C}_{16} \mathrm{H}_{16} \mathrm{~N}_{2} \mathrm{O}_{3}$ : C, 67.59; N, 9.85; H, 5.67. Found: C, 67.47; N, 9.79; H, 5.74.

3-Ethoxy-2-[2-(6-methoxy-pyridin-2-yl)ethyl]-2,3-dihydro-isoindol-1-one (8). To a solution of $0.25 \mathrm{~g}(1.0 \mathrm{mmol})$ of phthalimide 6 in $25 \mathrm{~mL}$ of THF at $-78^{\circ} \mathrm{C}$ was added $3.5 \mathrm{~mL}$ ( $\left.3.5 \mathrm{mmol}\right)$ of a $1.0 \mathrm{M}$ lithium triethylborohydride solution. The reaction mixture was allowed to stir for $15 \mathrm{~min}$ and then quenched with $5 \mathrm{~mL}$ of a $10 \% \mathrm{HCl} / \mathrm{EtOH}$ solution and stirred for an additional $2 \mathrm{~h}$. The reaction was neutralized with sodium carbonate and extracted with ether. The combined organic layers were dried over magnesium sulfate and concentrated under reduced pressure. The crude residue was subjected to flash silica gel chromatography to give $0.19 \mathrm{~g}(70 \%)$ of 8 as a clear oil; IR (neat) 1704, 1600, 1578, 1467, and $1070 \mathrm{~cm}^{-1}$; ${ }^{1} \mathrm{H}-\mathrm{NMR}\left(\mathrm{CDCl}_{3}, 300 \mathrm{MHz}\right) \delta 1.12$ (t, 3H, $J=6.9 \mathrm{~Hz}), 2.96-3.19(\mathrm{~m}, 4 \mathrm{H}), 3.70(\mathrm{p}, 1 \mathrm{H}, J=7.0 \mathrm{~Hz}), 3.81(\mathrm{~s}, 3 \mathrm{H}), 4.18(\mathrm{p}, 1 \mathrm{H}, J=$ $7.0 \mathrm{~Hz}), 5.74(\mathrm{~s}, 1 \mathrm{H}), 6.54(\mathrm{~d}, 1 \mathrm{H}, J=8.1 \mathrm{~Hz}), 6.75(\mathrm{~d}, 1 \mathrm{H}, J=7.2 \mathrm{~Hz}), 7.41-7.57(\mathrm{~m}, 4 \mathrm{H})$, and 7.77-7.80 (m, $1 \mathrm{H}) ;{ }^{13} \mathrm{C}-\mathrm{NMR}\left(\mathrm{CDCl}_{3}, 75 \mathrm{MHz}\right) \delta 15.3,36.2,39.3,53.3,58.1,86.5,108.5$, 115.9, 123.4, 123.5, 129.9, 132.0, 133.2, 139.1, 141.4, 156.8, 163.9, and 167.8; HRMS Calcd for $\mathrm{C}_{18} \mathrm{H}_{20} \mathrm{~N}_{2} \mathrm{O}_{3}: 312.1474$. Found: 312.1474 .

3-Methoxy-5,11b-dihydro-6H-4,6a-diazabenzo[c]fluoren-7-one (9). A solution of $0.1 \mathrm{~g}$ ( $0.4 \mathrm{mmol})$ of pyridine $7 \mathrm{in} 15 \mathrm{~mL}$ of benzene was added $2 \mathrm{mg}$ of $p$-toluenesulfonic acid. The 
reaction was mixture was refluxed for $8 \mathrm{~h}$ and the solution was evaporated under reduced pressure. The crude residue was subjected to flash silica gel chromatography to give $0.11 \mathrm{~g}$ (70\%) of 9 as a white solid: $\mathrm{mp} 123-124{ }^{\circ} \mathrm{C}$; IR (neat) $1681,1601,1575,1482$, and $1323 \mathrm{~cm}^{-1}$; ${ }^{1} \mathrm{H}-\mathrm{NMR}\left(\mathrm{CDCl}_{3}, 300 \mathrm{MHz}\right) \delta$ 2.85-2.92 (m, $\left.1 \mathrm{H}\right), 3.03-3.14(\mathrm{~m}, 1 \mathrm{H}), 3.44$ (ddd, $1 \mathrm{H}, J=14.4$, 9.9, and $4.8 \mathrm{~Hz}), 3.88(\mathrm{~s}, 3 \mathrm{H}), 4.66(\mathrm{ddd}, 1 \mathrm{H}, J=13.2,6.5$, and $2.4 \mathrm{~Hz}), 5.61(\mathrm{~s}, 1 \mathrm{H}), 6.66(\mathrm{~d}$, $1 \mathrm{H}, J=8.7 \mathrm{~Hz}), 7.46-7.51(\mathrm{~m}, 1 \mathrm{H}), 7.56(\mathrm{dt}, 1 \mathrm{H}, J=7.4$ and $0.9 \mathrm{~Hz}), 7.76(\mathrm{~d}, 1 \mathrm{H}, J=7.5 \mathrm{~Hz})$, and $7.85(\mathrm{t}, 2 \mathrm{H}, J=9.0 \mathrm{~Hz}) ;{ }^{13} \mathrm{C}-\mathrm{NMR}\left(\mathrm{CDCl}_{3}, 75 \mathrm{MHz}\right) \delta 32.6,37.6,53.7,58.4,109.3,122.3$, 123.1, 124.2, 128.8, 131.9, 132.7, 136.0, 144.5, 152.1, 162.9, and 168.0; Anal. Calcd for $\mathrm{C}_{16} \mathrm{H}_{14} \mathrm{~N}_{2} \mathrm{O}_{2}: \mathrm{C}, 70.17 ; \mathrm{N}, 10.52 ; \mathrm{H}, 5.30$. Found: $\mathrm{C}, 70.85 ; \mathrm{N}, 10.21 ; \mathrm{H}, 5.49$.

A solution of $0.17 \mathrm{~g}(0.6 \mathrm{mmol})$ of pyridine 8 in $15 \mathrm{~mL}$ of benzene was added $2 \mathrm{mg}$ of $p$ toluenesulfonic acid. The reaction was mixture was refluxed for $8 \mathrm{~h}$ and the solution was evaporated under reduced pressure. The crude residue was subjected to flash silica gel chromatography to give $0.14 \mathrm{~g}$ (55\%) of 3-methoxy-5,11b-dihydro-6H-4,6a-diazabenzo[c]fluoren-7-one (9) whose spectral properties were identical to a sample prepared by the cyclization of 7 .

2-(2-Methoxy-pyridin-4-yl)ethanol (12). A solution containing $1.0 \mathrm{~g}(8.0 \mathrm{mmol})$ of 2-methoxy3-methyl-pyridine 21 in $40 \mathrm{~mL}$ of dry THF at $-78{ }^{\circ} \mathrm{C}$ was treated dropwise with $3.6 \mathrm{~mL}$ $(9.0 \mathrm{mmol})$ of $2.5 \mathrm{M}$ solution of $n-\mathrm{BuLi}$ in hexane. The mixture was stirred at $-78{ }^{\circ} \mathrm{C}$ for $15 \mathrm{~min}$ and then $1.0 \mathrm{~g}(33 \mathrm{mmol})$ of paraformaldehyde was added and the resultant mixture was allowed to gradually warm to $\mathrm{rt}$ and stirred for an additional $5 \mathrm{~h}$. The mixture was quenched with $10 \mathrm{~mL}$ of water and the aqueous phase was extracted with ether. The combined organic layers were washed with $10 \mathrm{~mL}$ of brine and the combined organic layers were dried over sodium sulfate. The solvent was removed under reduced pressure and the residue was purified by silica gel chromatography to give $0.5 \mathrm{~g}(50 \%)$ of 12 as a colorless oil: IR (neat) 1613,1560, and $1397 \mathrm{~cm}^{-}$ ${ }^{1} \mathrm{H}-\mathrm{NMR}\left(\mathrm{CDCl}_{3}, 300 \mathrm{MHz}\right) \delta 1.63$ (brs, $\left.1 \mathrm{H}\right), 2.81(\mathrm{t}, 2 \mathrm{H}, J=6.6 \mathrm{~Hz}), 3.88(\mathrm{t}, 2 \mathrm{H}, J=6.6 \mathrm{~Hz})$, $3.92(\mathrm{~s}, 3 \mathrm{H}), 6.62(\mathrm{~s}, 1 \mathrm{H}), 6.76(\mathrm{dd}, 1 \mathrm{H}, J=5.1$ and $0.9 \mathrm{~Hz})$, and $8.07(\mathrm{~d}, 1 \mathrm{H}, J=5.1 \mathrm{~Hz}) ;{ }^{3} \mathrm{C}-$ NMR $\left(\mathrm{CDCl}_{3}, 75 \mathrm{MHz}\right) \delta 38.5,53.6,62.5,111.1,118.0,146.0,151.1$, and 164.6; HRMS Calcd for $\mathrm{C}_{8} \mathrm{H}_{11} \mathrm{NO}_{2}$ : 153.0790 . Found: 155.0790 .

2-[2-(2-Methoxy-pyridin-4-yl)ethyl]-isoindole-1,3-dione (13). A solution of $0.4 \mathrm{~g}$ (2.0 mmol) of diethyl azodicarboxylate in $5 \mathrm{~mL}$ of THF was added to a solution of $0.3 \mathrm{~g}(2.0 \mathrm{mmol})$ of alcohol 12, $0.3 \mathrm{~g}(2.0 \mathrm{mmol})$ of phthalimide, and $0.5 \mathrm{~g}(2.0 \mathrm{mmol})$ of triphenylphosphine in $30 \mathrm{~mL}$ THF at $0{ }^{\circ} \mathrm{C}$. The mixture was allowed to warm to $\mathrm{rt}$, stirred for $10 \mathrm{~h}$ and then concentrated under reduced pressure. The crude residue was subjected to flash silica gel chromatography to give $0.44 \mathrm{~g}(75 \%)$ of 13 as a white solid: $\mathrm{mp} 147-148{ }^{\circ} \mathrm{C}$; IR (neat) 1768 , 1707, 1611, 1399, 1183, and $706 \mathrm{~cm}^{-1} ;{ }^{1} \mathrm{H}-\mathrm{NMR}\left(\mathrm{CDCl}_{3}, 300 \mathrm{MHz}\right) \delta 2.94(\mathrm{t}, 2 \mathrm{H}, J=7.6 \mathrm{~Hz}$ ), $3.88(\mathrm{~s}, 3 \mathrm{H}), 3.92(\mathrm{t}, 2 \mathrm{H}, J=7.6 \mathrm{~Hz}), 6.61(\mathrm{~s}, 1 \mathrm{H}), 6.77(\mathrm{~d}, 1 \mathrm{H}, J=4.8 \mathrm{~Hz}), 7.68-7.71(\mathrm{~m}, 2 \mathrm{H})$, 7.80-7.83 (m, 2H), and $8.05(\mathrm{~d}, 1 \mathrm{H}, J=5.1 \mathrm{~Hz}) ;{ }^{13} \mathrm{C}-\mathrm{NMR}\left(\mathrm{CDCl}_{3}, 75 \mathrm{MHz}\right) \delta 33.9,38.2,53.6$, 111.0, 117.7, 123.5, 132.1, 134.2, 147.1, 149.8, 164.7, and 168.2; Anal. Calcd for $\mathrm{C}_{16} \mathrm{H}_{14} \mathrm{~N}_{2} \mathrm{O}_{3}$ : C, 68.08; N, 9.92; H, 5.00. Found: C, 68.17; N, 9.88; H, 4.96.

3-Hydroxy-2-[2-(2-methoxy-pyridin-4-yl)ethyl]-2,3-dihydro-isoindol-1-one (14). To a 
solution of $0.8 \mathrm{~g}(3.0 \mathrm{mmol})$ of phthalimide 13 in $25 \mathrm{~mL}$ of THF at $-78{ }^{\circ} \mathrm{C}$ was added $9 \mathrm{~mL}$ $(9.0 \mathrm{mmol})$ of a $1.0 \mathrm{M}$ lithium triethylborohydride solution. The reaction mixture was allowed to stir for $15 \mathrm{~min}$ and then quenched with $1 \mathrm{~mL}$ of $10 \% \mathrm{HCl}$, neutralized with sodium carbonate, and extracted with ether. The combined organic layers were dried over magnesium sulfate and concentrated under reduced pressure. The crude residue was subjected to flash silica gel chromatography to give $0.75 \mathrm{~g}(90 \%)$ of $\mathbf{1 4}$ as a white solid: $\mathrm{mp} 128-129{ }^{\circ} \mathrm{C}$; IR (neat) 1699 , $1673,1615,1450$, and $1398 \mathrm{~cm}^{-1}$; ${ }^{1} \mathrm{H}-\mathrm{NMR}\left(\mathrm{CDCl}_{3}, 300 \mathrm{MHz}\right) \delta 2.81-2.91(\mathrm{~m}, 2 \mathrm{H}), 3.50-3.59$ (m, 1H), 3.63-3.73 (m, 1H), $3.84(\mathrm{~s}, 3 \mathrm{H}), 4.24(\mathrm{~d}, 1 \mathrm{H}, J=10.5 \mathrm{~Hz}), 5.60(\mathrm{~d}, 1 \mathrm{H}, J=10.0 \mathrm{~Hz})$, $6.54(\mathrm{~s}, 1 \mathrm{H}), 6.70(\mathrm{~d}, 1 \mathrm{H}, J=5.1 \mathrm{~Hz}), 7.38-7.43(\mathrm{~m}, 1 \mathrm{H}), 7.50-7.60(\mathrm{~m}, 3 \mathrm{H})$, and $7.94(\mathrm{~d}, 1 \mathrm{H}, J=$ $5.4 \mathrm{~Hz}) ;{ }^{13} \mathrm{C}-\mathrm{NMR}\left(\mathrm{CDCl}_{3}, 75 \mathrm{MHz}\right) \delta 34.0,39.7,53.6,82.3,110.7,117.7,123.4,123.6,130.0$, 131.5, 132.5, 144.1, 147.0, 150.8, 164.7, and 167.7; Anal. Calcd for $\mathrm{C}_{16} \mathrm{H}_{16} \mathrm{~N}_{2} \mathrm{O}_{3}: \mathrm{C}, 67.59 ; \mathrm{N}$, 9.85; H, 5.67. Found: C, 67.67; N, 9.85; H, 5.69.

3-Methoxy-5,11b-dihydro-6H-2,6a-diaza-benzo[c]fluoren-7-one (15). A solution of $0.2 \mathrm{~g}$ $(0.7 \mathrm{mmol})$ of amide $14 \mathrm{in} 15 \mathrm{~mL}$ of benzene was added $2 \mathrm{mg}$ of $p$-toluenesulfonic acid. The reaction was mixture was refluxed for $8 \mathrm{~h}$ and the solution was evaporated under reduced pressure. The crude residue was subjected to flash silica gel chromatography to give $0.09 \mathrm{~g}$ (49\%) of 15 as a white solid: $\mathrm{mp} 168-169^{\circ} \mathrm{C}$; IR (neat) $1692,1609,1557$, and $1401 \mathrm{~cm}^{-1} ;{ }^{1} \mathrm{H}$ NMR $\left(\mathrm{CDCl}_{3}, 300 \mathrm{MHz}\right) \delta 2.79-2.87(\mathrm{~m}, 1 \mathrm{H}), 2.92,3.03(\mathrm{~m}, 1 \mathrm{H}), 3.42(\mathrm{dd}, 1 \mathrm{H}, J=13.5,9.2$, and $5.1 \mathrm{~Hz}), 3.88(\mathrm{~s}, 3 \mathrm{H}), 4.44(\mathrm{dd}, 1 \mathrm{H}, J=13.1,6.0$, and $4.1 \mathrm{~Hz}), 5.64(\mathrm{~s}, 1 \mathrm{H}), 6.56(\mathrm{~s}, 1 \mathrm{H})$, $7.49(\mathrm{t}, 1 \mathrm{H}, J=7.4 \mathrm{~Hz}), 7.58-7.64(\mathrm{~m}, 1 \mathrm{H}), 7.84(\mathrm{t}, 2 \mathrm{H}, J=7.8 \mathrm{~Hz})$, and $8.42(\mathrm{~s}, 1 \mathrm{H}) ;{ }^{13} \mathrm{C} \mathrm{NMR}$ $\left(\mathrm{CDCl}_{3}, 75 \mathrm{MHz}\right) \delta 29.2,37.5,53.7,57.3,110.4,123.6,124.1,124.2,128.9,132.0,132.6,143.8$, 144.2, 146.8, 163.5, and 168.0; Anal. Calcd. $\mathrm{C}_{16} \mathrm{H}_{14} \mathrm{~N}_{2} \mathrm{O}_{2}: \mathrm{C}, 72.17$; H, 5.30; N, 10.52. Found; C, 71.88; H, 5.37: N, 10.47 .

The minor product isolated contained $0.04 \mathrm{~g}$ (19\%) of 1-methoxy-5,11b-dihydro- $6 \mathrm{H}-2,6 \mathrm{a}$ diaza-benzo[c]fluoren-7-one (16) as a white solid: $\mathrm{mp} 93-94{ }^{\circ} \mathrm{C}$; IR (neat) $1695,1595,1569$, 1399, and $1260 \mathrm{~cm}^{-1} ;{ }^{1} \mathrm{H}$ NMR $\left(\mathrm{CDCl}_{3}, 300 \mathrm{MHz}\right) \delta$ 2.62-2.70 (m, 1H), 2.85-2.96 (m, 1H), 3.12 (dt, $1 \mathrm{H}, J=12.5$ and $3.3 \mathrm{~Hz}), 4.16(\mathrm{~s}, 3 \mathrm{H}), 4.69-4.77(\mathrm{~m}, 1 \mathrm{H}), 5.92(\mathrm{~s}, 1 \mathrm{H}), 6.68(\mathrm{~d}, 1 \mathrm{H}, J=$ $5.1 \mathrm{~Hz}), 7.44-7.57(\mathrm{~m}, 2 \mathrm{H}), 7.86(\mathrm{~d}, 1 \mathrm{H}, J=7.4 \mathrm{~Hz}), 7.95(\mathrm{~d}, 1 \mathrm{H}, J=5.1 \mathrm{~Hz})$, and $8.13(\mathrm{~d}, 1 \mathrm{H}, J$ $=7.4 \mathrm{~Hz}) ;{ }^{13} \mathrm{C} \mathrm{NMR}\left(\mathrm{CDCl}_{3}, 75 \mathrm{MHz}\right) \delta 30.4,38.1,53.5,57.7,117.7,118.5,123.7,125.5$, 128.8, 132.2, 132.7, 144.8, 145.6, 147.0, 161.7, and 169.5; Anal. Calcd. $\mathrm{C}_{16} \mathrm{H}_{14} \mathrm{~N}_{2} \mathrm{O}_{2}: \mathrm{C}, 72.17$; H, 5.30; N, 10.52. Found; C, 71.88; H, 5.37: N, 10.47.

1-[2-(6-Methyoxy-pyridin-2-yl)ethyl]pyrrolidine-2,5-dione (17). A solution of $0.3 \mathrm{~g}$ $(1.6 \mathrm{mmol})$ of diethyl azodicarboxylate in $5 \mathrm{~mL}$ of THF was added to a solution of $0.3 \mathrm{~g}$ $(1.6 \mathrm{mmol})$ of alcohol $5,0.2 \mathrm{~g}(1.6 \mathrm{mmol})$ of phthalimide, and $0.4 \mathrm{~g}(1.6 \mathrm{mmol})$ of triphenylphosphine in $50 \mathrm{~mL}$ THF at $0{ }^{\circ} \mathrm{C}$. The mixture was allowed to warm to $\mathrm{rt}$, stirred for $10 \mathrm{~h}$ and then concentrated under reduced pressure. The crude residue was subjected to flash silica gel chromatography to give $0.3 \mathrm{~g}(70 \%)$ of 17 as a clear oil; IR (neat) 1775, 1704, 1601, 1581, and $1465 \mathrm{~cm}^{-1} ;{ }^{1} \mathrm{H}-\mathrm{NMR}\left(\mathrm{CDCl}_{3}, 300 \mathrm{MHz}\right) \delta 2.64(\mathrm{~s}, 4 \mathrm{H}), 2.94(\mathrm{t}, 2 \mathrm{H}, J=7.8 \mathrm{~Hz}), 3.90$ $(\mathrm{t}, 2 \mathrm{H}, J=7.8 \mathrm{~Hz}), 3.89$ (s, 3H), $6.54(\mathrm{~d}, 1 \mathrm{H}, J=8.4 \mathrm{~Hz}), 6.68(\mathrm{~d}, 1 \mathrm{H}, J=7.2 \mathrm{~Hz})$, and $7.43(\mathrm{dd}$, $1 \mathrm{H}, J=8.4$ and $7.2 \mathrm{~Hz}) ;{ }^{13} \mathrm{C}-\mathrm{NMR}\left(\mathrm{CDCl}_{3}, 75 \mathrm{MHz}\right) \delta 28.3,35.2,38.4,53.4,108.6,115.8$, 
138.9, 155.9, 163.8, and 177.2; Anal. Calcd for $\mathrm{C}_{12} \mathrm{H}_{14} \mathrm{~N}_{2} \mathrm{O}_{3}$ : C, 61.51; N, 11.96; H, 6.03. Found: C, 61.44; N, 11.82; H, 5.91.

5-Hydroxy-1-[2-(6-methoxy-pyridin-2-yl)ethyl]pyrrolidin-2-one (18). To a solution of $0.8 \mathrm{~g}$ (3.0 mmol) of imide 17 in $100 \mathrm{~mL}$ of THF at $-78^{\circ} \mathrm{C}$ was added $13 \mathrm{~mL}(13 \mathrm{mmol})$ of a $1.0 \mathrm{M}$ lithium triethylborohydride solution. The reaction mixture was allowed to stir for $15 \mathrm{~min}$ and then quenched with $5 \mathrm{~mL}$ of $10 \% \mathrm{HCl}$, neutralized with sodium carbonate, and extracted with ether. The combined organic layers were dried over magnesium sulfate and concentrated under reduced pressure. The crude residue was subjected to flash silica gel chromatography to give $0.5 \mathrm{~g}(70 \%)$ of 18 as a white solid: $\mathrm{mp} 79-80{ }^{\circ} \mathrm{C}$; IR (neat) $1668,1599,1579$, and $1466 \mathrm{~cm}^{-1} ;{ }^{1} \mathrm{H}-$ NMR $\left(\mathrm{CDCl}_{3}, 300 \mathrm{MHz}\right) \delta 1.86-1.95(\mathrm{~m}, 1 \mathrm{H}), 2.16-2.29(\mathrm{~m}, 2 \mathrm{H}), 2.45-2.56(\mathrm{~m}, 1 \mathrm{H}), 2.93-3.02$ (m, 1H), 3.04-3.12 (m, 1H), 3.52-3.61 (m, 1H), $3.90(\mathrm{~s}, 3 \mathrm{H}), 3.92-3.96(\mathrm{~m}, 1 \mathrm{H}), 5.19(\mathrm{~d}, 1 \mathrm{H}, J=$ $4.8 \mathrm{~Hz}), 5.64(\mathrm{brs}, 1 \mathrm{H}), 6.60(\mathrm{~d}, 1 \mathrm{H}, J=8.4 \mathrm{~Hz}), 6.78(\mathrm{~d}, 1 \mathrm{H}, J=7.2 \mathrm{~Hz})$, and $7.53(\mathrm{dd}, 1 \mathrm{H}, J=$ 8.4 and $7.2 \mathrm{~Hz}) ;{ }^{13} \mathrm{C}-\mathrm{NMR}\left(\mathrm{CDCl}_{3}, 75 \mathrm{MHz}\right) \delta 28.5,29.1,36.2,40.2,54.1,84.4,108.2,116.8$, 140.0, 157.4, 164.1, and 175.0; Anal. Calcd for $\mathrm{C}_{12} \mathrm{H}_{16} \mathrm{~N}_{2} \mathrm{O}_{3}$ : C, 61.00; N, 11.86; H, 6.83. Found: C, 60.95; N, 11.82; H, 6.79.

3-Methoxy-5,9,10,10a-tetrahydro-6H-pyrrolo[2,1-f][1,6]naphthyridin-8-one (19). A solution of $0.1 \mathrm{~g}(0.4 \mathrm{mmol})$ of pyridine $18 \mathrm{in} 25 \mathrm{~mL}$ of benzene was added $2 \mathrm{mg}$ of $p$-toluenesulfonic acid. The reaction was mixture was refluxed for $12 \mathrm{~h}$ and the solution was evaporated under reduced pressure. The crude residue was subjected to flash silica gel chromatography to give $0.01 \mathrm{~g}(20 \%)$ of 19 as a clear oil; IR (neat) 1731, 1695, 1669, and $1597 \mathrm{~cm}^{-1} ;{ }^{1} \mathrm{H}-\mathrm{NMR}\left(\mathrm{CDCl}_{3}\right.$, $300 \mathrm{MHz}) \delta 1.68-1.85(\mathrm{~m}, 2 \mathrm{H}), 2.43-2.66(\mathrm{~m}, 2 \mathrm{H}), 2.79-2.96(\mathrm{~m}, 2 \mathrm{H}), 2.99-3.09(\mathrm{~m}, 1 \mathrm{H}), 3.70$ (s, 3H), 4.38-4.44 (m, 1H), 4.70-4.75 (m, 1H), $6.63(\mathrm{~d}, 1 \mathrm{H}, J=8.4 \mathrm{~Hz})$, and $7.30(\mathrm{~d}, 1 \mathrm{H}, J=$ $8.4 \mathrm{~Hz}) ;{ }^{13} \mathrm{C}-\mathrm{NMR}\left(\mathrm{CDCl}_{3}, 75 \mathrm{MHz}\right) \delta 27.6,31.7,31.9,36.8,53.6,56.1,109.5,125.4,135.7$, 151.1, 162.7, and 173.3; Anal. Calcd for $\mathrm{C}_{12} \mathrm{H}_{14} \mathrm{~N}_{2} \mathrm{O}_{2}$ : C, 66.02; N, 12.84; H, 6.47. Found: $\mathrm{C}$, $65.87 ; \mathrm{N}, 12.73 ; \mathrm{H}, 6.35$.

2-(6-Methoxy-pyridin-2-yl)ethylamine (25). To a solution of imide 13 in $35 \mathrm{~mL}$ of absolute ethanol was added $0.4 \mathrm{~g}(13 \mathrm{mmol})$ of hydrazine hydrate and the solution was refluxed at $65^{\circ} \mathrm{C}$ for $2 \mathrm{~h}$. The precipitate was filtered and washed with $10 \mathrm{~mL}$ of ethanol and the solution was concentrated to provide $0.9 \mathrm{~g}$ (93\%) of 25 as a clear oil: IR (neat) 1599, 1578, 1463, and $1291 \mathrm{~cm}^{-1} ;{ }^{1} \mathrm{H}-\mathrm{NMR}\left(\mathrm{CDCl}_{3}, 300 \mathrm{MHz}\right) \delta 1.70(\mathrm{brs}, 2 \mathrm{H}), 2.82(\mathrm{t}, 2 \mathrm{H}, J=6.4 \mathrm{~Hz}), 3.10$ (t, $2 \mathrm{H}, J$ $=6.4 \mathrm{~Hz}), 3.91(\mathrm{~s}, 3 \mathrm{H}), 6.56(\mathrm{~d}, 1 \mathrm{H}, J=8.2 \mathrm{~Hz}), 6.72(\mathrm{~d}, 1 \mathrm{H}, J=7.2 \mathrm{~Hz})$, and $7.47(\mathrm{dd}, 1 \mathrm{H}, J=$ 8.2 and $7.2 \mathrm{~Hz}) ;{ }^{13} \mathrm{C}-\mathrm{NMR}\left(\mathrm{CDCl}_{3}, 75 \mathrm{MHz}\right) \delta 41.5,41.7,53.3,107.9,116.0,138.9,158.0$, and 163.9; HRMS Calcd for $\mathrm{C}_{8} \mathrm{H}_{12} \mathrm{~N}_{2} \mathrm{O}: 152.0950$. Found: 152.0948 .

Hept-6-enoic acid [2-(6-methoxy-pyridin-2-yl)ethyl]amide (28). To a solution containing 0.8 $\mathrm{g}(7.0 \mathrm{mmol})$ of hept-6-enoic acid (26) in $100 \mathrm{~mL}$ of $\mathrm{CH}_{2} \mathrm{Cl}_{2}$ was added $1.0 \mathrm{~g}(7.0 \mathrm{mmol})$ of 1,1'carbonyldiimidazole and the solution was stirred at $\mathrm{rt}$ for $2 \mathrm{~h}$. To this mixture was added $1.0 \mathrm{~g}$ $(6.6 \mathrm{mmol})$ of 5-methoxy-2-ethylamine-pyridine (25) at $0{ }^{\circ} \mathrm{C}$, and the solution was allowed to warm to rt, stirred for $8 \mathrm{~h}$, and concentrated under reduced pressure. The residue was subjected to flash silica gel chromatography to give $1.5 \mathrm{~g}(87 \%)$ of $\mathbf{2 8}$ as a colorless oil; IR (neat) 1644, 1600,1579 , and $1554 \mathrm{~cm}^{-1} ;{ }^{1} \mathrm{H}-\mathrm{NMR}\left(\mathrm{CDCl}_{3}, 300 \mathrm{MHz}\right) \delta 1.36(\mathrm{p}, 2 \mathrm{H}, J=7.8 \mathrm{~Hz}), 1.60(\mathrm{p}, 2 \mathrm{H}$, 
$J=7.8 \mathrm{~Hz}), 2.01(\mathrm{q}, 2 \mathrm{H}, J=7.2 \mathrm{~Hz}), 2.12(\mathrm{t}, 2 \mathrm{H}, J=7.8 \mathrm{~Hz}), 2.85(\mathrm{t}, 2 \mathrm{H}, J=6.3 \mathrm{~Hz}), 3.61(\mathrm{q}$, $2 \mathrm{H}, J=6.3 \mathrm{~Hz}), 3.89(\mathrm{~s}, 3 \mathrm{H}), 4.89-4.98(\mathrm{~m}, 2 \mathrm{H}), 5.67-5.81(\mathrm{~m}, 1 \mathrm{H}), 6.48$ (brs, $1 \mathrm{H}), 6.57(\mathrm{~d}, 1 \mathrm{H}$, $J=8.4 \mathrm{~Hz}), 6.68(\mathrm{~d}, 1 \mathrm{H}, J=7.2 \mathrm{~Hz})$, and $7.46(\mathrm{dd}, 1 \mathrm{H}, J=8.4$ and $7.2 \mathrm{~Hz}) ;{ }^{13} \mathrm{C}-\mathrm{NMR}\left(\mathrm{CDCl}_{3}\right.$, $75 \mathrm{MHz}) \delta$ 25.4, 28.6, 33.6, 36.7, 36.9, 38.7, 53.3, 108.5, 114.8, 116.1, 138.6, 139.3, 157.5, 163.8, and 172.9; Anal. Calcd for $\mathrm{C}_{15} \mathrm{H}_{22} \mathrm{~N}_{2} \mathrm{O}_{2}$ : C, 68.66; N, 10.68; H, 8.46. Found: C, 68.58; N, $10.73 ; \mathrm{H}, 8.27$.

3,7-Dimethyl-oct-6-enoic acid [2-(6-methoxy-pyridin-2-yl)ethyl]amide (29). To a solution containing $0.13 \mathrm{~g}(0.7 \mathrm{mmol})$ of citronellic acid (27) in $20 \mathrm{~mL}$ of $\mathrm{CH}_{2} \mathrm{Cl}_{2}$ was added $0.13 \mathrm{~g}$ $(0.8 \mathrm{mmol})$ of $1,1^{\prime}$-carbonyldiimidazole and the solution was stirred at $\mathrm{rt}$ for $2 \mathrm{~h}$. To this mixture was added $0.11 \mathrm{~g}(0.7 \mathrm{mmol})$ of 2-(6-methoxy-pyridin-2-yl)-ethylamine (25) at $0{ }^{\circ} \mathrm{C}$, and the solution was allowed to warm to $\mathrm{rt}$, stirred for $10 \mathrm{~h}$, and concentrated under reduced pressure. The residue was subjected to flash silica gel chromatography to give $0.13 \mathrm{~g}(60 \%)$ of 29 as a colorless oil; IR (neat) 1643, 1598, 1579, and $1466 \mathrm{~cm}^{-1} ;{ }^{1} \mathrm{H}-\mathrm{NMR}\left(\mathrm{CDCl}_{3}, 300 \mathrm{MHz}\right) \delta 0.89$ (d, $3 \mathrm{H}, J=8.4 \mathrm{~Hz}), 1.11-1.21(\mathrm{~m}, 1 \mathrm{H}), 1.25-1.39(\mathrm{~m}, 1 \mathrm{H}), 1.57(\mathrm{~s}, 3 \mathrm{H}), 1.66(\mathrm{~s}, 3 \mathrm{H}), 1.85-2.01(\mathrm{~m}$, $4 \mathrm{H}), 2.16(\mathrm{~m}, 1 \mathrm{H}), 2.89(\mathrm{t}, 2 \mathrm{H}, J=6.3 \mathrm{~Hz}), 3.66(\mathrm{q}, 2 \mathrm{H}, J=8.0 \mathrm{~Hz}), 3.92(\mathrm{~s}, 3 \mathrm{H}), 5.06(\mathrm{t}, 1 \mathrm{H}, J=$ $6.9 \mathrm{~Hz}), 6.39$ (brs, 1H), $6.60(\mathrm{~d}, 1 \mathrm{H}, J=8.4 \mathrm{~Hz}), 6.72(\mathrm{~d}, 1 \mathrm{H}, J=7.2 \mathrm{~Hz})$, and $7.49(\mathrm{dd}, 1 \mathrm{H}, J=$ 8.4 and $7.2 \mathrm{~Hz})$; ${ }^{13} \mathrm{C}-\mathrm{NMR}\left(\mathrm{CDCl}_{3}, 75 \mathrm{MHz}\right) \delta 17.9,19.7,25.7,25.9,30.7,36.7,37.2,38.8$, 45.1, 53.5, 108.6, 116.2, 124.6, 131.7, 139.4, 157.6, 163.9, and 172.5; HRMS Calcd for $\mathrm{C}_{18} \mathrm{H}_{28} \mathrm{~N}_{2} \mathrm{O}_{2}$ : 304.2151. Found: 304.2156.

$N$-Hept-6-enoyl- $N$-[2-(6-methoxy-pyridin-2-yl)ethyl]malonamic acid ethyl ester (30). $N$ Malonylacylation was carried out on amide 28 in the normal manner to give $1.6 \mathrm{~g}(75 \%)$ of 30 as a colorless oil; IR (neat) 1741, 1698, 1598, and $1415 \mathrm{~cm}^{-1}$; ${ }^{1} \mathrm{H}-\mathrm{NMR}\left(\mathrm{CDCl}_{3}, 300 \mathrm{MHz}\right) \delta 1.23$ (t, 3H, $J=7.2 \mathrm{~Hz}), 1.33(\mathrm{p}, 2 \mathrm{H}, J=7.8 \mathrm{~Hz}), 1.56(\mathrm{p}, 2 \mathrm{H}, J=7.5 \mathrm{~Hz}), 2.00(\mathrm{q}, 2 \mathrm{H}, J=7.2 \mathrm{~Hz})$, $2.51(\mathrm{t}, 2 \mathrm{H}, J=7.5 \mathrm{~Hz}), 2.93(\mathrm{t}, 2 \mathrm{H}, J=7.2 \mathrm{~Hz}), 3.79(\mathrm{~s}, 2 \mathrm{H}), 3.99(\mathrm{~s}, 3 \mathrm{H}), 4.05(\mathrm{t}, 2 \mathrm{H}, J=7.8$ $\mathrm{Hz}), 4.14$ (q, 2H, J=7.2 Hz), 4.89-4.99 (m, 2H), 5.67-5.80 (m, 1H), 6.55 (d, 1H, J=8.1 Hz), $6.69(\mathrm{~d}, 1 \mathrm{H}, J=7.2 \mathrm{~Hz})$, and $7.44(\mathrm{dd}, 1 \mathrm{H}, J=8.1$ and $7.2 \mathrm{~Hz}) ;{ }^{13} \mathrm{C}-\mathrm{NMR}\left(\mathrm{CDCl}_{3}, 75 \mathrm{MHz}\right) \delta$ 14.2, 24.1, 28.3, 33.5, 36.5, 36.9, 44.3, 46.6, 53.2, 61.3, 108.8, 114.9, 116.3, 138.3, 139.2, 155.8, 163.9, 167.5, 168.9, and 176.0; Anal. Calcd for $\mathrm{C}_{20} \mathrm{H}_{28} \mathrm{~N}_{2} \mathrm{O}_{5}: \mathrm{C}, 63.80$; N, 7.44; H, 7.50. Found: C, 63.71; N, 7.38; H, 7.29.

$N$-(3,7-Dimethyl-oct-6-enoyl)- $N$-[2-(6-methoxy-pyridin-2-ylethyl]malonamic acid ethyl ester (31). $N$-Malonylacylation was carried out on amide 29 in the normal manner to give $0.13 \mathrm{~g}$ (73\%) of 31 as a colorless oil; IR (neat) 1741, 1696, 1599, and $1579 \mathrm{~cm}^{-1} ;{ }^{1} \mathrm{H}-\mathrm{NMR}\left(\mathrm{CDCl}_{3}\right.$, $300 \mathrm{MHz}) \delta 0.88(\mathrm{~d}, 3 \mathrm{H}, J=6.6 \mathrm{~Hz}), 1.27(\mathrm{t}, 3 \mathrm{H}, J=6.9 \mathrm{~Hz}), 1.20-1.55(\mathrm{~m}, 3 \mathrm{H}), 1.58(\mathrm{~s}, 3 \mathrm{H})$, $1.67(\mathrm{~s}, 3 \mathrm{H}), 1.91-2.06(\mathrm{~m}, 3 \mathrm{H}), 2.30-2.40(\mathrm{~m}, 1 \mathrm{H}), 2.52(\mathrm{dd}, 1 \mathrm{H}, J=16.2$ and $5.4 \mathrm{~Hz}), 2.97(\mathrm{t}$, $2 \mathrm{H}, J=7.2 \mathrm{~Hz}), 3.84(\mathrm{~s}, 2 \mathrm{H}), 3.91(\mathrm{~s}, 3 \mathrm{H}), 4.06-4.12(\mathrm{~m}, 1 \mathrm{H}), 4.19$ (q, 2H, $J=6.9 \mathrm{~Hz}), 5.04-5.08$ $(\mathrm{m}, 1 \mathrm{H}), 6.60(\mathrm{~d}, 1 \mathrm{H}, J=8.1 \mathrm{~Hz}), 6.74(\mathrm{~d}, 1 \mathrm{H}, J=7.2 \mathrm{~Hz})$, and $7.48(\mathrm{dd}, 1 \mathrm{H}, J=8.1$ and 7.2 $\mathrm{Hz}) ;{ }^{13} \mathrm{C}-\mathrm{NMR}\left(\mathrm{CDCl}_{3}, 75 \mathrm{MHz}\right) \delta 14.3,17.9,19.8,25.7,25.9,29.5,37.0,37.1,44.0,44.5$, 46.7, 53.4, 61.4, 108.9, 116.4, 124.3, 131.8, 139.3, 155.8, 164.1, 167.7, 169.2, and 175.8; Anal. Calcd for $\mathrm{C}_{23} \mathrm{H}_{34} \mathrm{~N}_{2} \mathrm{O}_{5}$ : C, 65.99; N, 6.70; H, 8.19. Found: C, 65.76; N, 6.88; H, 8.29.

2-Diazo- $N$-hept-6-enoyl- $N$-[2-(6-methoxy-pyridin-2-yl)ethyl]malonamic acid ethyl ester 
(32). Imide 30 was subjected to the standard diazo transfer conditions to give $1.4 \mathrm{~g}(95 \%)$ of 32 as a yellow oil: IR (neat) 2138, 1721, 1701, 1652, and $1577 \mathrm{~cm}^{-1} ;{ }^{1} \mathrm{H}-\mathrm{NMR}\left(\mathrm{CDCl}_{3}, 300 \mathrm{MHz}\right)$ $\delta 1.25(\mathrm{t}, 3 \mathrm{H}, J=7.2 \mathrm{~Hz}), 1.37(\mathrm{p}, 2 \mathrm{H}, J=7.8 \mathrm{~Hz}), 1.61(\mathrm{p}, 2 \mathrm{H}, J=7.8 \mathrm{~Hz}), 2.02(\mathrm{q}, 2 \mathrm{H}, J=$ $7.2 \mathrm{~Hz}$ ), 2.49 (t, $2 \mathrm{H}, J=7.8 \mathrm{~Hz}$ ), 2.98 (t, $2 \mathrm{H}, J=7.2 \mathrm{~Hz}$ ), 3.87 (s, 3H), 4.04 (t, $2 \mathrm{H}, J=7.2 \mathrm{~Hz}$ ), 4.20 (q, 2H, $J=7.2 \mathrm{~Hz}), 4.89-5.00$ (m, 2H), 5.67-5.82 (m, 1H), 6.54 (d, 1H, $J=8.4 \mathrm{~Hz}), 6.68$ (d, $1 \mathrm{H}, J=7.2 \mathrm{~Hz})$, and $7.44(\mathrm{dd}, 1 \mathrm{H}, J=8.4$ and $7.2 \mathrm{~Hz}) ;{ }^{13} \mathrm{C}-\mathrm{NMR}\left(\mathrm{CDCl}_{3}, 75 \mathrm{MHz}\right) \delta 14.4$, $24.5,28.5,33.6,35.8,37.5,46.2,53.3,61.9,72.6,108.5,114.8,116.5,138.6,139.1,156.1$, $160.6,163.9,166.6$, and 175.5.

2-Diazo- $N$-(3,7-dimethyl-oct-6-eno-yl)- $N$-[2-(6-methoxy-pyridin-2-yl-ethyl]malo-namic acid ethyl ester (33). Imide 31 was subjected to the standard diazo transfer conditions to give $0.12 \mathrm{~g}$ $(90 \%)$ of 33 as a yellow oil: IR (neat) $2137,1722,1701$, and $1654 \mathrm{~cm}^{-1} ;{ }^{1} \mathrm{H}-\mathrm{NMR}\left(\mathrm{CDCl}_{3}\right.$, $300 \mathrm{MHz}) \delta 0.91(\mathrm{~d}, 3 \mathrm{H}, J=6.6 \mathrm{~Hz}), 1.14-1.23(\mathrm{~m}, 1 \mathrm{H}), 1.28(\mathrm{t}, 3 \mathrm{H}, J=7.2 \mathrm{~Hz}), 1.30-1.40(\mathrm{~m}$, $1 \mathrm{H}), 1.58(\mathrm{~s}, 3 \mathrm{H}), 1.68(\mathrm{~s}, 3 \mathrm{H}), 1.91-2.06(\mathrm{~m}, 3 \mathrm{H}), 2.32(\mathrm{dd}, 1 \mathrm{H}, J=15.8$ and $7.8 \mathrm{~Hz}), 2.52(\mathrm{dd}$, $1 \mathrm{H}, J=15.8$ and $5.7 \mathrm{~Hz}$ ), $3.01(\mathrm{t}, 2 \mathrm{H}, J=7.2 \mathrm{~Hz}), 3.90(\mathrm{~s}, 3 \mathrm{H}), 4.06(\mathrm{t}, 2 \mathrm{H}, J=7.2 \mathrm{~Hz}), 4.23(\mathrm{q}$, $2 \mathrm{H}, J=7.2 \mathrm{~Hz}), 5.07(\mathrm{t}, 1 \mathrm{H}, J=9.0 \mathrm{~Hz}), 6.56(\mathrm{~d}, 1 \mathrm{H}, J=8.4 \mathrm{~Hz}), 6.71(\mathrm{~d}, 1 \mathrm{H}, J=7.2 \mathrm{~Hz})$, and $7.46(\mathrm{dd}, 1 \mathrm{H}, J=8.4$ and $7.2 \mathrm{~Hz}) ;{ }^{13} \mathrm{C}-\mathrm{NMR}\left(\mathrm{CDCl}_{3}, 75 \mathrm{MHz}\right) \delta 14.5,17.9,19.9,25.7,25.9$, $30.1,37.1,37.5,43.3,46.3,53.4,62.0,72.8,108.6,116.6,124.5,131.7,139.2,156.2,160.6$, $163.9,166.9$, and 174.9.

\section{0-[2-(6-Methoxy-pyridin-2-yl)ethyl]-9-oxo-11-oxa-10-aza-tricyclo[6.2.1.01,6]un-decane-8-}

carboxylic acid ethyl ester (34). A solution containing $1.1 \mathrm{~g}(3.0 \mathrm{mmol})$ of diazoimide 32 in $50 \mathrm{~mL}$ of $\mathrm{CH}_{2} \mathrm{Cl}_{2}$ at $\mathrm{rt}$ was treated with $5 \mathrm{mg}$ of rhodium(II) perfluorobutyrate. The reaction mixture was stirred for $12 \mathrm{~h}$ at $\mathrm{rt}$ and was concentrated under reduced pressure. The resulting residue was purified by flash silica gel chromatography to give $1.0 \mathrm{~g} \mathrm{(92 \% )}$ of 34 as a colorless oil; IR (neat) 1750, 1722, 1598, and $1464 \mathrm{~cm}^{-1} ;{ }^{1} \mathrm{H}-\mathrm{NMR}\left(\mathrm{CDCl}_{3}, 300 \mathrm{MHz}\right) \delta 1.07-1.17(\mathrm{~m}$, 2H), 1.32 (t, 3H, $J=6.9 \mathrm{~Hz}), 1.59-1.75(\mathrm{~m}, 5 \mathrm{H}), 1.86-2.01$ (m, 2H), 2.08-2.17 (m, 2H), 2.79-2.99 $(\mathrm{m}, 2 \mathrm{H}), 3.47-3.57(\mathrm{~m}, 1 \mathrm{H}), 3.61-3.70(\mathrm{~m}, 1 \mathrm{H}), 3.89(\mathrm{~s}, 3 \mathrm{H}), 4.28-4.38(\mathrm{~m}, 2 \mathrm{H}), 6.55(\mathrm{~d}, 1 \mathrm{H}, J=$ $8.1 \mathrm{~Hz}), 6.70(\mathrm{~d}, 1 \mathrm{H}, J=7.2 \mathrm{~Hz})$, and $7.45(\mathrm{dd}, 1 \mathrm{H}, J=8.1$ and $7.2 \mathrm{~Hz}) ;{ }^{13} \mathrm{C}-\mathrm{NMR}\left(\mathrm{CDCl}_{3}\right.$, $75 \mathrm{~Hz}) \delta 14.4,21.6,24.6,27.4,32.7,37.0,37.2,39.5,42.1,53.4,62.2,86.0,96.9,108.5,116.2$, 139.2, 156.2, 163.9, 166.3, and 171.4; Anal. Calcd for $\mathrm{C}_{20} \mathrm{H}_{26} \mathrm{~N}_{2} \mathrm{O}_{5}$ : C, 64.16; H, 7.00; N, 7.48. Found: C, 64.00; H, 6.91; N, 7.37.

\section{0-[2-(6-Methoxy-pyridin-2-yl)ethyl]-3,7,7-trimethyl-9-oxo-11-oxa-10-aza-tricyclo-}

[6.2.1.01,6] undecane-8-carboxylic acid ethyl ester (35). A solution containing $0.05 \mathrm{~g}$ $(0.1 \mathrm{mmol})$ of diazoimide $33 \mathrm{in} 15 \mathrm{~mL}$ of $\mathrm{CH}_{2} \mathrm{Cl}_{2}$ at $\mathrm{rt}$ was treated with $2 \mathrm{mg}$ of rhodium(II) perfluorobutyrate. The reaction mixture was stirred for $12 \mathrm{~h}$ at $\mathrm{rt}$ and was concentrated under reduced pressure. The resulting residue was purified by flash silica gel chromatography to give $0.04 \mathrm{~g}(82 \%)$ of 35 as a colorless oil; IR (neat) 1744, 1723, 1573, and $1460 \mathrm{~cm}^{-1} ;{ }^{1} \mathrm{H}-\mathrm{NMR}$ $\left(\mathrm{CDCl}_{3}, 300 \mathrm{MHz}\right) \delta 0.72-0.84(\mathrm{~m}, 1 \mathrm{H}), 0.88(\mathrm{~d}, 3 \mathrm{H}, J=6.3 \mathrm{~Hz}), 1.00(\mathrm{~s}, 3 \mathrm{H}), 1.15(\mathrm{~s}, 3 \mathrm{H})$, $1.22-1.29(\mathrm{~m}, 2 \mathrm{H}), 1.34(\mathrm{t}, 3 \mathrm{H}, J=7.2 \mathrm{~Hz}), 1.39-1.54(\mathrm{~m}, 1 \mathrm{H}), 1.58-1.60(\mathrm{~m}, 3 \mathrm{H}), 1.87-1.91(\mathrm{~m}$, $1 \mathrm{H}), 2.86-2.98(\mathrm{~m}, 2 \mathrm{H}), 3.56-3.73(\mathrm{~m}, 2 \mathrm{H}), 3.92(\mathrm{~s}, 3 \mathrm{H}), 4.31-4.41(\mathrm{~m}, 2 \mathrm{H}), 6.57(\mathrm{~d}, 1 \mathrm{H}, J=$ $8.4 \mathrm{~Hz}), 6.72(\mathrm{~d}, 1 \mathrm{H}, J=7.2 \mathrm{~Hz})$, and $7.46(\mathrm{dd}, 1 \mathrm{H}, J=8.4$ and $7.2 \mathrm{~Hz}) ;{ }^{13} \mathrm{C}-\mathrm{NMR}\left(\mathrm{CDCl}_{3}\right.$, 
$75 \mathrm{MHz}) \delta 14.6,21.0,22.2,26.3,26.5,28.3,33.0,36.3,37.5,39.7,44.7,51.4,53.5,61.8,92.0$, 96.2, 108.5, 116.6, 139.2, 156.3, 163.9, 165.5, and 169.8; Anal. Calcd for $\mathrm{C}_{23} \mathrm{H}_{32} \mathrm{~N}_{2} \mathrm{O}_{5}$ : C, $66.31 ; \mathrm{N}, 6.73 ; \mathrm{H}, 7.75$. Found: C, 66.25; N, 6.77; H, 7.66.

\section{3-Hydroxy-1-[2-(6-methoxy-pyridin-2-yl)ethyl]-oxo-1,2,3,4,5,6,7,8-octahydroquino-line-3-} carboxylic acid ethyl ester (36). A solution of $0.15 \mathrm{~g}(0.4 \mathrm{mmol})$ of cycloadduct 34 in $25 \mathrm{~mL}$ of benzene was added $2 \mathrm{mg}$ of $p$-toluenesulfonic acid. The reaction was mixture was refluxed for $12 \mathrm{~h}$ and the solution was evaporated under reduced pressure. The crude residue was subjected to flash silica gel chromatography to give $0.14 \mathrm{~g}(93 \%)$ of 36 as a clear oil; IR (neat) 1738, 1667, 1598, and $1465 \mathrm{~cm}^{-1} ;{ }^{1} \mathrm{H}-\mathrm{NMR}\left(\mathrm{CDCl}_{3}, 400 \mathrm{MHz}\right) \delta 1.23(\mathrm{t}, 3 \mathrm{H}, J=7.2 \mathrm{~Hz}), 1.34-1.43(\mathrm{~m}, 2 \mathrm{H})$, 1.60-1.65 (m, 1H), 1.72-1.77 (m, 1H), 1.96-2.00 (m, 3H), 2.16-2.22 (m, 1H), 2.29-2.33 (m, 1H), $2.57(\mathrm{~d}, 1 \mathrm{H}, J=15.6 \mathrm{~Hz}), 2.83-2.99(\mathrm{~m}, 2 \mathrm{H}), 3.75-3.82(\mathrm{~m}, 1 \mathrm{H}), 3.91(\mathrm{~s}, 3 \mathrm{H}), 4.14-4.22(\mathrm{~m}, 2 \mathrm{H})$, 4.59 (brs, $1 \mathrm{H}), 6.56(\mathrm{~d}, 1 \mathrm{H}, J=8.0 \mathrm{~Hz}), 6.70(\mathrm{~d}, 1 \mathrm{H}, J=7.2 \mathrm{~Hz})$, and $7.44(\mathrm{dd}, 1 \mathrm{H}, J=8.0$ and $7.2 \mathrm{~Hz}) ;{ }^{13} \mathrm{C}-\mathrm{NMR}\left(\mathrm{CDCl}_{3}, 100 \mathrm{MHz}\right) \delta 14.3,22.1,22.8,25.1,29.2,35.0,36.6,41.9,53.4,61.8$, 73.7, 108.4, 114.6, 116.1, 131.3, 138.9, 156.3, 163.9, 168.6, and 170.1; Anal. Calcd for $\mathrm{C}_{20} \mathrm{H}_{26} \mathrm{~N}_{2} \mathrm{O}_{5}$ : C, 64.14; N, 7.48; H, 7.00. Found: C, 64.02; N, 7.53; H, 7.09.

\section{Acknowledgments}

We gratefully acknowledge support of this work by the National Institutes of Health (GM59384 and GM60003).

\section{References}

1. (a) Mondon, A.; Hansen, K. F.; Boehme, K.; Faro, H. P.; Nestler, H. J.; Vilhuber, H. G.; Böttcher, K. Chem. Ber. 1970, 103, 615. (b) Mondon, A.; Seidel, P. R. Chem. Ber. 1971, 104, 2937. (c) Mondon, A.; Nestler, H. J. Chem. Ber. 1979, 112, 1329.

2. Hiemstra, H.; Speckamp, W. N. Comprehensive Organic Synthesis; Trost, B. M.; Fleming, I. Eds; Pergamon: Oxford, 1991; Vol. 2, pp 1047-1082.

3. (a) Kametani, T.; Fukumoto, K. The Chemistry of Heterocyclic Compounds, Isoquinoline Part One; Grethe, G., Ed.; Wiley: New York; pp 170-182. (b) Jones, G. Comprehensive Heterocyclic Chemistry; Katritzky, A. R., Rees, C. W., Eds; Pergamon: Oxford, 1984; Vol. 2, pp 438-440. (c) Padwa, A.; Brodney, M. A.; Marino, J. P.; Sheehan, S. M. J. Org. Chem. 1997, 62, 78 .

4. (a) Speckamp, W.N. Recl. Trav. Chim. Pays Bas. 1981, 100, 345. (b) Veenstra, S.J.; Speckamp, W.N. J. Am. Chem. Soc. 1981, 103. 4645. (c) Wijnberg, B.P.; Speckamp, W.N. Tetrahedron Lett. 1981, 22, 5079. 
5. (a) Hart, D.J. J. Org. Chem. 1981, 46, 367. (b) Hart, D.J. J. Org. Chem. 1981, 46, 3576. (c) Hart, D.J.; Kanai, K. J. Org. Chem. 1982, 47, 1555. (d) Hart, D.J.; Yang, T.K. Tetrahedron Lett. 1982, 23, 2671. (e) Hart, D.J.; Kanai, K. J. Am. Chem. Soc. 1983, 105, 1255.

6. Whaley, W.H.; Govindachari, T.R. Org. React. Wiley: New York, 1951; pp 151-206.

7. (a) Langkopf, E.; Schinzer, D. Chem. Rev. 1995, 95, 1375. (b) Hong, C.Y.; Kado, N.; Overman, L.E. J. Am. Chem. Soc. 1993, 115, 11028. (c) Ofial, A.R.; Mayr, H. J. Org. Chem. 1996, 61, 5823.

8. (a) Franklin, A.S.; Overman, L.E. Chem. Rev. 1996, 96, 505. (b) Blumankopf, T.A.; Overman, L.E. Chem. Rev. 1996, 86, 857.

9. Reviews: (a) Gellert, E. In Alkaloids: Chemical and Biological Perspectives; Pelletier, S.W., Ed.; John Wiley and Sons: New York, NY, 1987; Vol. 5. (b) Suffness, M.; Cordell, G.A. In The Alkaloids; Brossi, A., Ed.; Academic Press: Orlando, FL, 198. Vol. 25, p 156. (c) Bick, R.C.; Sinchai, W. In The Alkaloids; Rodrigo, R.G.A., Ed.; Academic Press: New York, 1981; Vol. 19, p 193. (d) Govindachari, T.R. In The Alkaloids; Manske, R.H.F., Ed.; Academic Press: New York, 1967; Vol. 9, p 517.

10. Reviews: (a) Pyridine and its Derivatives, Supplemental Edn.; Abramovitch, R.A. WileyInterscience: New York, 1974. (b) Smith, D.M. In Comprehensive Organic Chemistry Vol. 4, Sammes, P.G., Ed.; Pergamon: Oxford, 1979. (c) Heterocyclic Chemistry, Gilchrist, T. L. Pitman Publ. Ltd.: London, 1985.

11. Comins, D.L.; Joseph, S.P. In Comprehensive Heterocyclic Chemistry 2, McKillop, A. Ed. Elsevier Science Ltd.: Oxford, 1996.

12. Gray, M. A.; Konopski, L.; Langlois, Y. Synthetic Commun. 1994, 24, 1367.

13. Mitsunobu, O. Synthesis 1981, 1.

14. Fisher, M. L.; Overman, L. E. J. Org. Chem. 1990, 55, 1447.

15. Osterhout, M. H.; Nadler, W. R.; Padwa, A. Synthesis 1994, 123.

16. Padwa, A.; Weingarten, M. D. Chem. Rev. 1996, 96, 223.

17. Padwa, A.; Hertzog, D. L.; Nadler, W. R. J. Org. Chem. 1994, 59,7072.

18. Padwa, A.; Brodney, M. A.; Marino, J. P. Jr.; Osterhout, M. H.; Price, A. T. J. Org. Chem. 1997, 62, 67.

19. Padwa, A.; Brodney, M. A.; Marino, J. P. Jr.; Sheehan, S. M. J. Org. Chem. 1997, 62,78.

20. (a) Sato, M.; Kanuma, N.; Kato, T. Chem. Pharm. Bull. 1982, 30, 1315. (b) Regitz, M.; Hocker, J.; Leidhergener, A. Org. Synth. John Wiley: New York, 1973; Collect. Vol. 5, p 179.

21. Adger, B. M.; Ayrey, P.; Bannister, R.; Forth, M. A.; Hajikarimian, Y.; Lewis, N. J. J. Chem. Soc., Perkin Trans. I 1988, 2791. 